Voluntad. A la voluntad alude Marañón cuando finaliza este ensayo, pero la necesitamos todos, jóvenes, maduros y viejos, en el hombre y en la mujer, para ponernos en nuestro lugar, para comportarnos con los que están en otra edad, para el trabajo, para el dolor, para el estudio. Voluntad para dejarlo todo antes de acomodarse a lo ilegal, vehemencia juvenil en todas las edades para oponerse a la injusticia.

Es de esperar que la juventud española pueda cumplir las promesas contenidas en las bellas palabras de Filgueira que hemos transcrito.

\section{Sobre J. C. Mariátegui}

Un grupo de escritores jóvenes del Perú, César Barrio, Jorge Basadre, Carlos Raygada, Luis Alberto Sánchez, nuestro conocido, y Alcides Spelucin, han fundado un periódico, Presente, calificado de «inactual s por sus fundadores, y en el que, dándole una orientación francamente crítica y artística, se proponen formar un grupo, grupo de acción cultural, que seguramente será tan necesario en Lima como en Santiago. Entre nosotros, el propósito similar ha sido cumplido con la publicación de Indice.

En el número que tenemos a la vista, de Julio del presente año, destaca un estudio de Luis Alberto Sánchez, sobre Mariátegui; titulado Datos para una semblanza de $J$. Carlos Mariátegui, del cual extractamos los párrafos principales:

Para seguir más de cerca la orientación y la obra de José Carlos, es preciso prescindir de la devo- ción beata, de la emoción intensa y decisiva de los primeros instantes, intentar un bosquejo de su evolución, objetivamente, marcando los hitos, a fin de no incurrir en ninguno de los dos extremos en que fácilmente se cae cuando se roza una personalidad de tal calibre.

Relata la infancia de Mariátegui, sus debilidades físicas que lo acompañaron desde su nacimiento, y su iniciación, allá por 1910, como periodista en La Prensa.

En La Prensa pontificaban, en esos días, La Jara, Yerovi, Cisneros; Piérola y sus conspiradores; Ulloa y sus editoriales. Los poetas predilectos de entonces-lo fueron también de Mariátegui-Herrera Reissig, Darío y Chocano, llenaron su imaginación de frases sonoras y giros rebuscados. Amanecía un americanismo retórico. La generación de Ariel-los García Calderón, Riva Agüero, Bealunde, Gálvez-imponía el sello de su aristarquía en Lima. Era la hora cenital del modernismo y el decadentismo; de la sonoridad verbal. El cojito Mariátegui atisbaba desde su rincón de pinche del periódico, a los escritores universitarios orgullosos de entonces. De ahí nació quizás su primera disconformidad con lo universitario y con el seudo americanismo.

Permanece en el periodismo Mariátegui, y su tendencia frívola y literaturizante se manifestaba en sus crónicas (firmaba eJuan Croniqueur?) y en la vida de bohemia literaria que hacía junto con sus compañeros de letras, Valdelomar, Ladislao Meza, More, etc. Pero ya lo dominaban las inquietudes sociales y cuando se fundó el Partido Socialista ,peruano reclamó un lu- 
gar en las filas. Las alternativas de la situación política de su patria le impedian permanecer mucho tiempo en determinados periódicos, hasta que junto con Falcón $\mathrm{y}$ del Aguila, fundó La Razón en 1919.

La Razón criticó irónicamente al señor Leguía. Promovió la reforma universitaria. Protestó, cuando los sonados motines proletarios del 27 al 30 de Mayo de 1919, contra las medidas drásticas asumidas por el gobierno. Fué el campeón de la necesidad de libertar a Gutarra, Barba, Fonken y demás cabecillas obreros presos. Sus redactores sostuvieron al comité de Reforma Estudiantil, que surgió porque la Federación de Estudiantes contemporizaba con el profesorado y no tenía belicosidad suficiente. A raíz de los sucesos del 4 de Julio que llevaron al Gobierno al señor Leguía, La Razón declaró su esperanza en que el nuevo régimen encarnara un movimiento renovador efectivo. Alguna vez aplaudió al señor Cornejo. Pero al producirse el decreto sobre reformas constitucionales, inició una labor de análisis valiente y censura franca a casi todas las reformas. En Agosto aun se publicaba el diario, pero se cernían amenazas sobre su suerte. Su último editorial fué uno en blanco, como los que usaba $\mathrm{El}$ Sol de Madrid en los principios del Gobierno de Primo. Luego circuló un boletín anunciando que $L a$ Razón no podría seguirse publicando. Mariátegui y Falcón se encontraban en situación harto difícil. Como consecuencia de ello aceptaron viajar al extranjero. Así fué como ambos partieron del Perú.

Su estada en Europa fué un acontecimiento capital para su vida $\mathrm{y}$ para su pensamiento:

La permanencia de Mariátegui en Europa duró hasta principios de 1923. Le tocó asistir a la época más aguda de la política mundial. Eran los días de auge del comunismo en Italia-y en Italia residió la mayor parte de aquellos cuatro años Mariátegui-, cuando los obreros se apoderaron de las fábricas. Le tocó además presenciar la reac ción conservadora, la iniciación de la marcha fascista. Estuvo en Alemania en la época del gobierno socialista y de la más apasionada discusión de los problemas sociales y políticos. La transguerra con su séquito de problemas complejos desfiló ante los ojos absortoside Mariátegui, para quien fué aquella una ocasión de confirmar sus ideas socialistas, ya fijadas en la campaña de Lima.

Ẹn Europa, además, conoció el fuerte amor. Se unió en matrimonio con una italiana, Anita Chiappe, la cual sería la compañera de su vida. En Italia nació su hijo primogénito. Las mutaciones ideológicas coincidieron con las mutaciones de su estado civil.

De su permanencia en Europa arrancan, pues, varios sucesos:

a) concentración en su vida, matrimonio, paternidad.

b) liberación de todo elemento literario puro de su estilo.

c) confirmación de su socialismo y marcha hacia el comunismo.

ch) conocimiento fundamental del marxismo y estudios económicos.

d) meditación sobre el panorama político y social de América.

e) mayor fuerza en sus sentimientos peruanistas, a través de su experiencia europea.

f) convencimiento de la necesidad de organizar conciencia y grupo, antes de lanzarse a la acción, combatiendo el caudillismo, siempre provisional.

g) fortalecimiento de su fe en el estudiantado y el proletariado, ya patente desde las campañas de $L a$ Razón. 
Su labor posterior es demasiado conocida y Sánchez no nos aporta dato alguno de novedad. Amauta, Claridad, Labor, y toda la acción social de Mariátegui, están demasiado cercanas a nosotros para que las hayamos olvidado y para tener ya un historiador.

Después, ayer no más, su muerte llorada:

Tuve la noticia de su muerteleyendo la de su sepelio-el 19 de Abril en el Callao. A la velada en homenaje y en beneficio de sus hijos, acudió modestísima concurrencia, como a las conferencias de Frank. A su sepelio, una muchedumbre de obreros y estudiantes, con rojas banderolas y cantando $L a$ Internacional. De los homenajes rendidos a su memoria, el más significativo de todos ha sido el de la Argentina; luego el del Uruguay, el de Chile, y el de Cuba. En Estados Unidos se realiza también la colecta pro-hijos de Mariátegui. El más insignificante de los homenajes $\mathrm{y}$ el más incomprensivo, el de la prensa del Perú. Bueno es tener presente que en 1925 se propuso el nombre de José Carlos para una cátedra universitaria, de su especialidad, pero que se le vetó. Hay quien le ha enrostrado, después de muerto, el habér sido dueño de un bello estilo, sin reparar que más bella fué su actitud moral y que, bajo el estilo, afluía un pensamiento robusto $y$ definitivamente sistematizado y porvenirista. Para enterrar su cuerpo, hubo que realizar una colecta entre los amigos más allegados. Deja tres libros inéditos, varios hijos, el socialismo iniciado en el Perú y la discusión en torno a su figura. Además, un punto de concentración, pese a todas las discrepancias: fué un HOMBRE.

El homenaje a Mariátegui, a que se refiere Sánchez, en el bello estudio de que hemos dado cuenta, que se le hizo de parte de la intelectualidad cubana, está contenido en el N. ${ }^{\circ} 47$ de 1930 , la revista de los escritore: cubanos de avanzada. Escriben en él Waldo Frank, Juan Marinello, Lino Novás Calvo, Jorge Mañach, Adolfo Zamora, que da una impresión sobre Mariátegui, concisa y acertada, Félix Lizaso, Medardo Vitier y Francisco Ichaso. El número de 1930 a que nos referimos está completado por una sección destinada a los libros, en que se destaca una impresión crítica sobre El roto, la popular novela de Joaquín Edwards Bello.

\section{LA SITUACIÓN CUBANA}

El N. ${ }^{\circ} 48$ de la misma revista cubana trae, entre otros, un editorial debido a la pluma de Jorge Mañach, indicador del espíritu de la revista y significativo del actual estado político cubano. Se titula Economía, Política, Cultura y dice lo siguiente:

En la considerable reducción presupuestal que acaban de acordar nuestras Cámaras, quedan empequeñecidos notablemente los créditos afectos a la enseñanza pública. Supresión de cátedras, fusión peregrina de materias disímiles, rebaja, a límites increíbles, de la retribución profesoral, mantenimiento de planes incompletos e ineficaces, en vigor a título interino.

Como queda bien a las claras, una vez más la cultura no cuenta entre las preocupaciones de gobernantes y políticos. ¿Para qué tan gran cantidad de maestros, tanto catedrático inútil? se han dicho 